\title{
Prevalence and distribution of QPX, Quahog Parasite Unknown, in hard clams Mercenaria mercenaria in Virginia, USA
}

\author{
Lisa M. Ragone Calvo*, Juanita G. Walker, Eugene M. Burreson \\ School of Marine Science, Virginia Institute of Marine Science, College of William and Mary, Gloucester Point, \\ Virginia 23062, USA
}

\begin{abstract}
In July 1996, the Virginia Institute of Marine Science initiated a sampling program to examine wild and cultured hard clams Mercenaria mercenaria for QPX, Quahog Parasite Unknown, a protistan parasite associated with severe mortalities of hard clams in localized areas in maritime Canada and Massachusetts, USA. The sampling program set out to seasonally monitor wild clams from one site, James River, Virginia, and cultured clams from 2 sites, Chincoteague Bay and Mattawoman Creek, Virginia. Histological examination of initial samples revealed $8 \%$ prevalence of the parasite in 1-2 yr old cultured clams in Chincoteague Bay. This is the first documentation of QPX in Virginia. To ascertain the distribution of the parasite in Virginia, the survey was expanded between August 1996 and July 1997 to include 16 additional sites. A total of 1305 wild and cultured clams was sampled from Chesapeake Bay tributaries and coastal areas where harvest and culture occur. QPX was not found in Chesapeake Bay, but was present in cultured clams from 3 coastal embayments - the original Chincoteague Bay site, Burton Bay and Quinby Inlet. The parasite was found in Chincoteague Bay at each sample period at prevalences ranging from 8 to $48 \%$. Infections were generally light to moderate intensity and were most often observed in mantle and gill tissues. The maximum prevalence was observed in May 1997 and coincided with notable clam mortalities. QPX prevalences at the other sites were low, ranging from 4 to $15 \%$. To date QPX has not had a significant impact on Virginia's hard clam fishery and aquaculture industry; however, the presence of the pathogen in 3 of the state's most productive hard clam growout areas warrants continued monitoring and research.
\end{abstract}

KEY WORDS: QPX · Hard clams · Quahog · Mercenarla mercenaria - Virginia - Disease · Parasite

\section{INTRODUCTION}

Epizootics of a protistan parasite, QPX (Quahog Parasite Unknown), have recently occurred in localized populations of cultured hard clams Mercenaria mercenaria in Prince Edward Island, Canada, and Massachusetts, USA. The parasite was first observed in the late 1950s in New Brunswick, Canada, where it was associated with mass mortalities in a population of densely set wild hard clams (Drinnan \& Henderson 1963). A similar parasite was found in wild clams from Barnegat Bay, New Jersey, in 1976 (Smolowitz et al. 1998) and in Prince Edward Island, in 1989 (Whyte et al. 1994), where it was associated with significant mortalities of

•E-mail:ragone@vims.edu juvenile and adult cultured hard clams held in a hatchery. In the summer and fall of 1995, a QPX-like protist was identified as the cause of high mortalities of cultured hard clams at 2 sites on the coast of Massachusetts, Provincetown and Duxbury (Smolowitz et al. 1998). Mortalities were observed in all sizes of clams; the most severely affected were those just under market size. While clam culturists in Provincetown had observed increasingly severe mortalities of their clam stocks since 1992, the outbreak in Duxbury was sudden and affected clams that had been exhibiting good growth. High prevalences of QPX and associated hard clam mortalities continue to occur in these 2 areas (Smolowitz pers. comm.).

Aspects of the life cycle, taxonomy, and epizootiology of QPX are poorly understood. Based on ob- 
served developmental stages of the parasite, QPX tentatively has been placed in the phylum Labyrinthomorpha in either the family Thraustochytriidae or Labyrinthulidae (Whyte et al. 1994). Members of this phylum are primarily saprotrophic members of marine and estuarine environments, and are usually associated with detrital sediments, benthic algae, and marine plants (Porter 1989). However, the phylum also contains several disease-causing organisms (McLean \& Porter 1982, Bower 1987, Hanlon \& Forsythe 1990).

The occurrence of QPX in New England caused growing concern among hard clam culturists located along the eastern seaboard of the United States. Interstate transplantations of clams are common, increasing the potential risk of disease transfer. in Virginia, hard clams are an important seafood product. The meat value of the wild harvest clam fishery for 1996 was $\$ 4.2$ million (Virginia Marine Resources Commission data) and hard clam aquaculture supplied over $\$ 8.0$ million in gross sales in 1995 (Anonymous 1996). Hard clams represent the most important aquaculture species in the state, accounting for $41 \%$ of total production dollars, and with continued expansion planned, clam aquaculture in Virginia is projected to have a dockside value in excess of $\$ 10$ million by the year 2000 (Anonymous 1996). Historically, disease has never been a problem for Virginia's hard clam fishery and aquaculture industry. However, having observed catastrophic disease losses of Virginia's oyster resource, industry members have been particularly concerned about the potential threat of QPX. In response to these concerns, the Virginia Institute of Marine Science (VIMS) began surveying Virginia's wild and cultured hard clam populations for QPX in the summer of 1996. This report documents findings of that survey.

\section{MATERIALS AND METHODS}

Collection of hard clams. Cultured and wild hard clams were collected from July 1996 through July 1997. To examine seasonal variability in parasite prevalence 3 sites were selected to be repeatedly sampled throughout the year. The 3 sites were: Black Narrows, Chincoteague Bay-a cultured clam growout location on the Atlantic coast of Virginia's Eastern Shore (the lower portion of a peninsula situated between the Chesapeake Bay and the Atlantic Ocean); Mattawoman Creek-a cultured clam growout location on the eastern shore of the Chesapeake Bay; and the lower James River (south of Brown Shoal) - a wild clam harvest area located on the western shore of the Cheaspeake Bay (Fig. 1). After discovering the para- site at 1 site in July 1996, the survey was broadened to determine the distribution of the parasite. Samples of cultured hard clams were subsequently collected from 14 additional sites and wild clams were collected from an additional 5 sites. The additional cultured clam survey sites included Chincoteague Bay (Cockles Creek), Bogues Bay, Metomkin Bay, Burton Bay (Big Wye Channel, Great Channel, Cedar Island), Quinby Inlet (Sandy Island), Magothy Bay, and Smith Island Bay on the Atlantic coast of Virginia's Eastern Shore peninsula; Hungars Creek, Cherrystone Creek, and Plantation Creek on the eastern shore of the Chesapeake Bay; and the North River and Bennett Creek on the western shore of the Chesapeake Bay (Fig. 1). Additional wild clam survey sites included Toms Cove, Burton Bay (Cedar Island and Big Wye Channel), and Quinby Inlet (Sandy Island) on the Atlantic coast of Virginia's Eastern Shore peninsula; and the lower York River (Gloucester Point) on the western shore of the Chesapeake Bay (Fig. 1). The sample program relied on the cooperation of industry members and was conducted with an open door policy, whereby clam growers and harvesters were encouraged to submit samples from any site at their convenience. For most sites, samples were collected only once during the year with most sites being sampled in either summer 1996 or spring 1997. In some instances multiple samples, representing various seed sources or age classes, were received from the same site.

Disease diagnosis. Following collection the clams were transported to the laboratory at VIMS and immediately processed for disease diagnosis. Shell heights of the largest and smallest clams in the sample were measured and recorded, gross pathological signs were noted, and cross-sections of clam tissues were preserved in Davidson's AFA (Howard \& Smith 1983). Fixed tissues were processed following standard paraffin histological techniques and $5 \mu \mathrm{m}$ thick sections were cut and stained with Harris' hematoxylin and eosin (H\&E) (Howard \& Smith 1983). Stained sections were examined with an Olympus BH light microscope and tissues infected and QPX infection intensity were noted. Infection intensity was categorized based on the number of parasite cells per total tissue section area as follows; rare ( $1-10$ cells), light ( $11-100$ cells), moderate $(101-1000$ cells) and heavy ( $>1000$ cells). Side by side comparisons of histological sections of QPX in Massachussetts and Virginia clams were made in collaboration with R. Smolowitz.

Selected specimens were resectioned and stained with Grocott's methanamine silver (GMS) for the demonstration of mucin, and Alcian Blue/Periodic Acid Schiff (AB/PAS) for the differentiation of PAS positive tissues and acid and neutral mucopolysaccharides (Howard \& Smith 1983). 


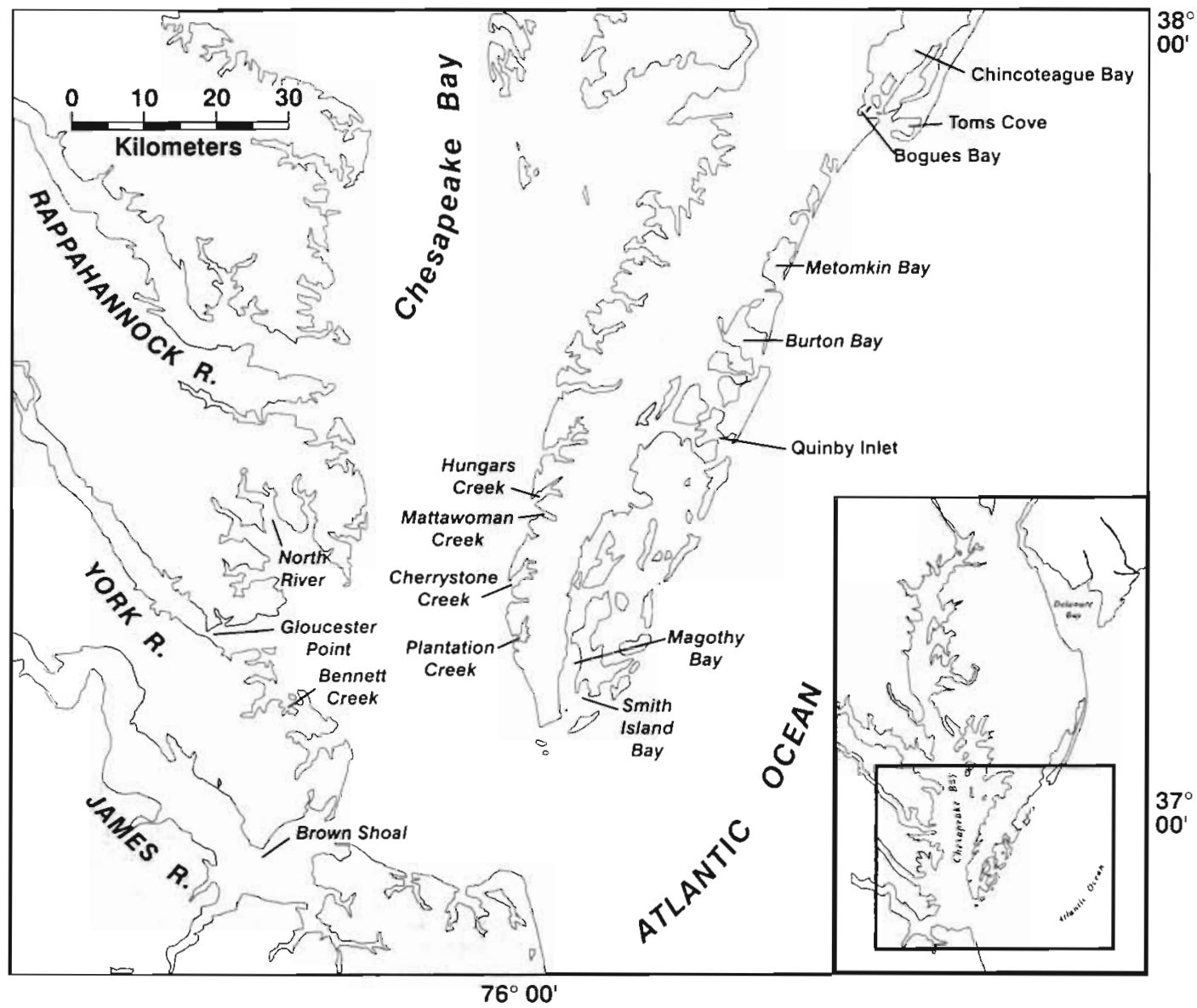

Fig. 1. Lower Chesapeake Bay showing hard clam survey sites on the mainland and Eastern Shore of Virginia

\section{RESULTS}

\section{Distribution and prevalence of QPX in Virginia}

Fifty-six clam samples, approximately 1305 clams, were examined during the 1 yr survey. Forty-four samples were collected from cultured clam stocks and the remaining 12 samples were collected from wild clam populations. Cultured clams originated from 11 hatcheries. Most samples contained clams that were 1.5 to $3 \mathrm{yr}$ in age (i.e. 25 to $35 \mathrm{~mm}$ shell height); however, a few samples contained smaller or larger clams. Overall, shell heights ranged from 19 to $89 \mathrm{~mm}$. Survey results for cultured and wild clam samples are presented in Tables 1 and 2, respectively.

QPX was observed in cultured hard clams from 3 different sites but was not detected in wild clams. However, tissue inclusions resembling degraded QPX cells were noted in 1 sample from Toms Cove. The 3 sites where QPX was found were Chincoteague Bay (Black Narrows), Quinby Inlet (Sandy Island), and Burton Bay (Big Wye Channel). All 3 embayments are part of a barrier-island-salt-marsh lagoonal system located on the Atlantic side of Virginia's Eastern Shore. The sites are located behind barrier islands and are characterized as shallow, high salinity ( 30 to $34 \mathrm{ppt}$ ) areas. These growout sites typify the primary hard clam culture areas in Virginia. QPX was not detected in either the moderate-salinity (15 to $25 \mathrm{ppt}$ ) creeks on the eastern shore of the Chesapeake Bay or in the 2 moderate-salinity culture sites sampled on the western shore of the Chesapeake Bay.

QPX was detected histologically in all samples analyzed from Black Narrows, Chincoteague Bay with prevalence ranging from 7 to $48 \%$ (Table 1). The prevalence of QPX in July was low; infections were observed in only 2 of the $25(8 \%)$ clams examined. Both infections were of light intensity and several moribund parasite cells were observed. Moribund and dead parasite cells appeared crenulated, intensely eosinophilic, or as an 'empty' cell wall. In August prevalence increased to $20 \%$; infection intensities remained low and most QPX cells were moribund. In the fall 3 different plots were sampled at Black Narrows. Clams at the various plots originated from 2 different 
Table 1. Mercenaria mercenaria. Prevalence and intensity of QPX in cultured hard clams from various grow-out sites in Virginia Infection intensity is designated as heavy $(\mathrm{H})$, moderate $(\mathrm{M})$ or light/rare (L). Values shown represent the number of clams with the designated level of infection intensity. The hatchery from which the clams originated is noted by an anonymous seed source code and, when known, the year spawned is also indicated

\begin{tabular}{|c|c|c|c|c|c|c|}
\hline Sample date & Site & $\begin{array}{l}\text { Seed source, } \\
\text { (Year spawned) }\end{array}$ & $\begin{array}{c}\text { Shell } \\
\text { height (mm) }\end{array}$ & $\mathrm{n}$ & $\begin{array}{c}\text { Prevalence } \\
(\%)\end{array}$ & $\begin{array}{l}\text { Intensity } \\
(\mathrm{H}-\mathrm{M}-\mathrm{L})\end{array}$ \\
\hline & $\begin{array}{l}\text { Atlantic Coast } \\
\text { Chincoteague Bay }\end{array}$ & & & & & \\
\hline 17 Jul 1996 & Black Narrows & 1 (1994) & $20-35$ & 25 & 8 & $0-0-2$ \\
\hline 26 Aug 1996 & Black Narrows & $1(1994)$ & $25-35$ & 25 & 20 & $0-0-5$ \\
\hline 29 Oct 1996 & Black Narrows & $2(1994)$ & $25-41$ & 28 & 7 & $0-0-1$ \\
\hline 29 Oct 1996 & Black Narrows & $1(1994)$ & $30-38$ & 26 & 15 & $0-0-4$ \\
\hline 14 Nov 1996 & Black Narrows & $1(1994)$ & $32-34$ & 25 & 28 & $0-4-3$ \\
\hline 14 Nov 1996 & Black Narrows & $2(1994)$ & $27-36$ & 25 & 12 & $0-1-2$ \\
\hline 14 Nov 1996 & Black Narrows & $1,2(1994)$ & $30-45$ & 25 & 16 & $0-0-4$ \\
\hline 19 Feb 1997 & Black Narrows & $1(1994)$ & $26-28$ & 28 & 14 & $0-0-4$ \\
\hline 1 May 1997 & Black Narrows & $1(1.994)$ & $28-32$ & 23 & 48 & $1-3-7$ \\
\hline 3 Jun 1997 & Black Narrows & 1 (1994) & $26-41$ & 26 & 15 & $0-0-4$ \\
\hline 26 Aug 1996 & Cockles Creek & & $30-39$ & 25 & 0 & $0-0-0$ \\
\hline 3 Jun 1997 & Bogues Bay & 1 & $33-46$ & 15 & 0 & $0-0-0$ \\
\hline 26 Aug 1996 & Metomkin Bay & 3 & $28-34$ & 21 & 0 & $0-0-0$ \\
\hline 22 May 1997 & Metomkin Bay & 4 & $28-36$ & 24 & 0 & $0-0-0$ \\
\hline \multirow[t]{2}{*}{22 May 1997} & Metomkin Bay & 5 & $13-26$ & 26 & 0 & $0-0-0$ \\
\hline & Burton Bay & & & & & \\
\hline 20 Feb 1997 & Big Wye Channel & $6(1994)$ & $46-51$ & 22 & 9 & $0-0-2$ \\
\hline 20 Feb 1997 & Big Wye Channel & $6(1995)$ & $24-31$ & 25 & 0 & $0-0-0$ \\
\hline 25 Mar 1997 & Big Wye Channel & $6(1987)$ & $57-63$ & 25 & 4 & $0-0-1$ \\
\hline 25 Mar 1997 & Big Wye Channel & $6(1994)$ & $34-56$ & 25 & 12 & $0-1-2$ \\
\hline 2 May 1997 & Big Wye Channel & $6(1995)$ & $30-33$ & 20 & 15 & $0-0-3$ \\
\hline 2 May 1997 & Big Wye Channel & 7 & $26-29$ & 11 & 0 & $0-0-0$ \\
\hline 10 Jun 1997 & Cedar Island & $8(1995)$ & $22-33$ & 25 & 0 & $0-0-0$ \\
\hline 10 Jun 1997 & Cedar Island & $8(1995)$ & $14-39$ & 23 & 0 & $0-0-0$ \\
\hline 22 May 1997 & Great Channel & $6(1996)$ & $8-10$ & 26 & 0 & $0-0-0$ \\
\hline 22 May 1997 & Great Channel & $6(1996)$ & $9-13$ & 25 & 0 & $0-0-0$ \\
\hline 30 Aug 1996 & Quinby Inlet & 1 & $29-37$ & 25 & 8 & $0-0-2$ \\
\hline 26 Sep 1996 & Quinby Inlet & 1 & $41-46$ & 25 & 0 & $0-0-0$ \\
\hline 5 Nov 1996 & Quinby Inlet & 1 & $41-48$ & 27 & 0 & $0-0-0$ \\
\hline 16 Aug 1996 & Magothy Bay & $5(1994)$ & & 25 & 0 & $0-0-0$ \\
\hline 30 May 1997 & Smith Island Bay & 5 & $33-39$ & 12 & 0 & $0-0-0$ \\
\hline 2 Jun 1997 & Smith Island Bay & 9 & $32-44$ & 25 & 0 & $0-0-0$ \\
\hline 16 Aug 1996 & $\begin{array}{l}\text { Eastern Chesapeake Bay } \\
\text { Hungars Creek }\end{array}$ & 1 & & 25 & 0 & $0-0-0$ \\
\hline 16 Jul 1996 & Mattawoman Creek & $5(1993)$ & $<35$ & 25 & 0 & $0-0-0$ \\
\hline 16 Aug 1996 & Mattawoman Creek & $5(1993)$ & $<35$ & 25 & 0 & $0-0-0$ \\
\hline 6 Nov 1996 & Mattawoman Creek & $5(1993)$ & $31-40$ & 25 & 0 & $0-0-0$ \\
\hline $25 \operatorname{Mar} 1997$ & Mattawoman Creek & $5(1993)$ & $28-38$ & 25 & 0 & $0-0-0$ \\
\hline 30 May 1997 & Mattawoman Creek & $5(1993)$ & $34-39$ & 12 & 0 & $0-0-0$ \\
\hline 2 Jun 1997 & Mattawoman Creek & 9 & $34-45$ & 25 & 0 & $0-0-0$ \\
\hline 16 Aug 1996 & Cherrystone Creek & $9(1994)$ & & 25 & 0 & $0-0-0$ \\
\hline 2 Jun 1997 & Cherrystone Creek & $9(1994)$ & $33-43$ & 25 & 0 & $0-0-0$ \\
\hline 2 Jun 1997 & Plantation Creek & 9 & $34-47$ & 25 & 0 & $0-0-0$ \\
\hline & Western Chesapeake Bay & & & & & \\
\hline 23 Aug 1996 & North River & 10 & $30-41$ & 25 & 0 & $0-0-0$ \\
\hline 20 Aug 1996 & Bennett Creek & 11 (1994) & $<35$ & 25 & 0 & $0-0-0$ \\
\hline 26 May 1997 & Bennett Creek & $11(1994)$ & $25-33$ & 25 & 0 & $0-0-0$ \\
\hline
\end{tabular}

hatcheries but were the same year class. QPX was present at all 3 plots and prevalences ranged from 7 to $25 \%$ i infection intensities were light to moderate. In several clams dead or dying parasites were observed; in others the parasite appeared active as various life stages were observed. Prevalence was $14 \%$ in February and most parasite cells observed were moribund. The maximum observed prevalence, $48 \%$, occurred in 
Table 2. Mercenaria mercenaria. Prevalence and intensity of QPX in wild hard clams from various harvest areas in Virginia. Infection intensity is designated as heavy $(\mathrm{H})$, moderate $(\mathrm{M})$ or light/rare (L). Values shown represent the number of clams with the designated level of infection intensity

\begin{tabular}{|c|c|c|c|c|c|}
\hline Sample date & Site & $\begin{array}{l}\text { Shell height } \\
\qquad(\mathrm{mm})\end{array}$ & $\mathrm{n}$ & $\begin{array}{c}\text { Prevalence } \\
(\%)\end{array}$ & $\begin{array}{l}\text { Intensity } \\
\text { (H-M-L) }\end{array}$ \\
\hline 18 Feb 97 & $\begin{array}{l}\text { Atlantic Coast } \\
\text { Toms Cove }\end{array}$ & $26-30$ & 25 & 0 & $0-0-0$ \\
\hline 3 Jun 97 & Bogues Bay & $67-89$ & 10 & 0 & $0-0-0$ \\
\hline $25 \operatorname{Mar} 97$ & Burton Bay & $19-52$ & 23 & 0 & $0-0-0$ \\
\hline $14 \operatorname{Mar} 97$ & Burton Bay, Cedar Island & & 12 & 0 & $0-0-0$ \\
\hline $14 \operatorname{Mar} 97$ & $\begin{array}{l}\text { Burton Bay, } \\
\text { Wachapreague Flats }\end{array}$ & & 15 & 0 & $0-0-0$ \\
\hline 4 Sep 96 & Quinby Inlet & $51-61$ & 25 & 0 & $0-0-0$ \\
\hline $10 \mathrm{Jul} 96$ & $\begin{array}{l}\text { Western Chesapeake Bay } \\
\text { James River, Brown Shoal }\end{array}$ & & 25 & 0 & $0-0-0$ \\
\hline 11 Sep 96 & James River, Brown Shoal & l $26-28$ & 25 & 0 & $0-0-0$ \\
\hline 24 Oct 96 & James River, Brown Shoal & $130-33$ & 25 & 0 & $0-0-0$ \\
\hline 24 Feb 97 & James River, Brown Shoal & l $31-33$ & 25 & 0 & $0-0-0$ \\
\hline 27 May 97 & James River, Brown Shoal & l $28-36$ & 25 & 0 & $0-0-0$ \\
\hline 27 May 97 & $\begin{array}{l}\text { York River, } \\
\quad \text { Gloucester Point }\end{array}$ & $58-66$ & 25 & 0 & $0-0-0$ \\
\hline
\end{tabular}

\section{Appearance of QPX in host tissues}

QPX infections were most frequently located in the connective tissue of the mantle and in the intralamellar spaces and water tubules of the gills. Of the infected clams, $63 \%$ exhibited mantle tissue infections and $35 \%$ had gill infections. Infections were also noted in the musculature of the foot, sinuses and connective tissue of the kidney, and sinuses and connective tissue adjacent to digestive glands. The percentages of infected clams having infections in foot, kidney, and visceral mass tissues were, respectively, 4,11 and $15 \%$.

Three parasite life stages, thalli, sporangia and endospores, were observed in the host tissues. In accordance with Smolowitz et al. (1998) classical mycological terminology has been adopted here. The most frequently observed May 1997. Abnormal clam mortalitiy, estimated to be 10 to $20 \%$, was reported by the grower at this time and the May sample was the only sample containing a heavily infected clam. As in November, various life stages of the parasite were observed. Prevalence declined to $15 \%$ in June 1997.

QPX was found in 2 of the $25(8 \%$ ) clams examined from Sandy Island, Quinby Inlet in August. One of the infected clams exhibited a multifocal light intensity infection in which numerous moribund parasite cells were observed. A multifocal moderate intensity infection was observed in the other infected clam. Some moribund parasite cells were present. The parasite was not detected at Sandy Island in September and November.

QPX was observed in 3 different stocks from Burton Bay. All 3 stocks originated from the same hatchery but were spawned in different years (1987, 1994 and 1995). Clams ranged in size from 24 to $63 \mathrm{~mm}$. Prevalence was 4 to $15 \%$ and infection intensities were light with the exception of 1 moderate infection.

\section{Gross pathology}

No gross lesions were apparent during necropsy of the sampled clams. Mantle tissues were free of notable swelling and nodules such as those reported by Smolowitz et al. (1998) were absent. There was no indication of chipped valve margins, which has also been reported as a clinical sign of QPX infection (Smolowitz et al. 1998). cell was the thallus, which appeared as a spherical cell ranging from 2 to $20 \mu \mathrm{m}$ in diameter (Figs 2 to 7 ). The cytoplasm of the thalli was weakly eosinophilic and enclosed in a basophilic cell wall which varied in thickness and in staining intensity (Figs. 2 to 3). Nuclear morphology was poorly defined using light microscopy and it was not possible to determine whether uni- and multinucleate stages were present. Thalli were usually surrounded by a cell-free region which typically was $<8 \mu \mathrm{m}$ thick (Fig. 3). Often, when numerous parasite cells were present in a focal lesion, large lucent areas devoid of host cells were formed (Fig. 4). In numerous hematoxylin and eosin preparations an extracellular basophilic filamentous or granular material which appeared to be radiating from the cell wall was observed in the cell-free area (Figs. 5 to 6). Inconsistency in the presence or absence of this material was probably related to loss of material material during histological processing. There was little evidence of necrosis in adjacent host tissues and occasionally hemocytes were present in the otherwise lucent areas encompassing QPX cells (Fig. 4). When stained with AB/PAS, extracellular material adjacent to the cell wall of the parasite stained bright blue indicating the material was mucoid in nature (Fig. 7). GMS staining of QPX was variable both within and between tissue sections of individual clams. In varying degrees the cell wall or cytoplasm of the parasite was positively stained.

In several clams, both thalli and sporangia were observed (Figs 8). Sporangia, which ranged from 20 to $48 \mu \mathrm{m}$ in diameter, contained 20 to 40 small round endospores that were each 1.5 to $2 \mu \mathrm{m}$ in diameter 


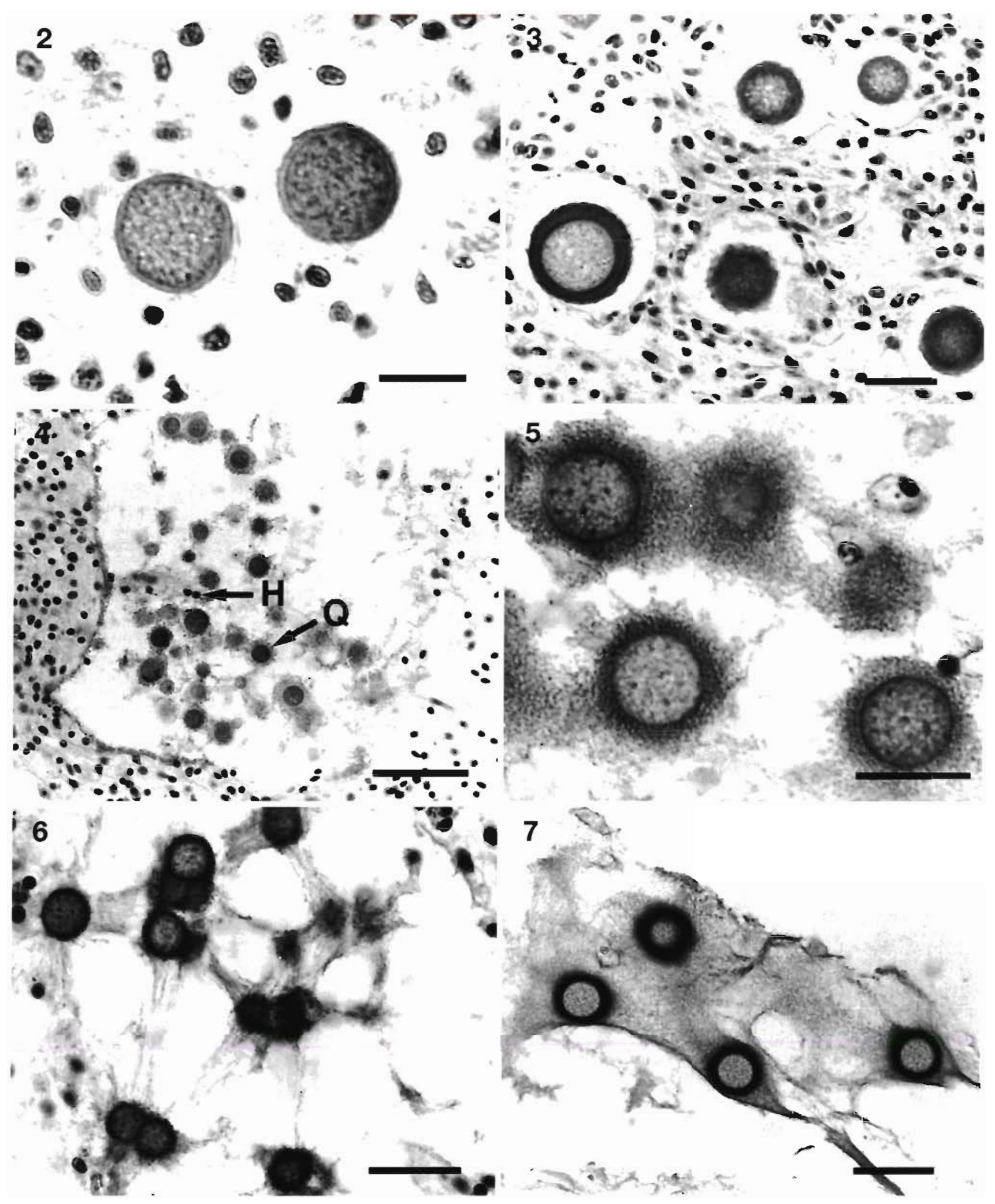

Figs. 2 to 7. QPX in hard clam Mercenaria mercenaria tissue. Fig. 2. QPX thalli in connective tissue (H\&E, scale bar $=10 \mu \mathrm{m})$. Fig. 3. Thick-walled QPX thalli and surrounding cell-free region $(\mathrm{H} \& \mathrm{E}$, scale bar $=20 \mu \mathrm{m})$. Fig. 4. QPX (Q) infection focus with large lucent area; several host hemocytes $(\mathrm{H})$ can be seen in lucent area (H\&E, scale bar $=\overline{50 \mu m})$. Figs. $5 \& 6$. QPX thalli sur-

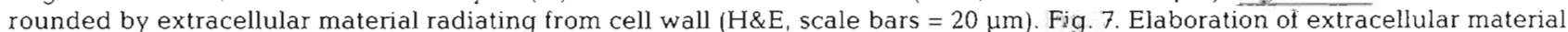
surrounding QPX thalli (AB/PAS, scale bar $=40 \mu \mathrm{m})$ 
(Figs. 9 to 11). Endospores, or immature thalli, exhibited a basophilic cell wall similar to the mature thalli. Differentiation of the endospore nuclear material was difficult using light microscopy; however, it appeared that both uni- and multinucleate endospores were present (Figs. 9 to 10). As the endospores enlarged, the cell wall of the sporangia disrupted and the immature thalli, 3 to $5 \mu \mathrm{m}$ in diameter, were released (Figs. 11 to 13). Similar to mature thalli, the cell wall of the immature thalli also stained intensely blue with AB/PAS. Sporangia were most abundant in clams that were collected in the fall and in the spring.

\section{Host response}

The parasite elicited an intense host response which generally included hemocyte infiltration (Figs. 14 to 16), phagocytosis (Fig. 18), and encapsulation (Figs. 17 \& 19). On occasion giant multinucleated hemocytes similar to those described by Smolowitz et al. (1998) were observed (Fig. 18). These giant cells apparently phagocytosed the parasite (Fig. 18). Cellular defense activities were often associated with moribund parasite cells (Fig. 19).

\section{DISCUSSION}

This survey of cultured and wild hard clams revealed that QPX is present at 3 sites in Virginia. This is the first documentation of QPX in Virginia. However, since hard clams in Virginia have never been extensively surveyed for parasites and diseases, we cannot ascertain whether the parasite has a long history in the area.

The 3 locations where QPX was found share similar geographic and hydrographic characteristics; all 3 sites are located in high salinity ( 30 to $34 \mathrm{ppt}$ ), shallow coastal lagoons on Virginia's Eastern Shore. Mercenaria mercenaria inhabits areas having salinities from 15 to 35 ppt (Kraeuter \& Castagna 1989). QPX was not detected in moderate salinity Chesapeake Bay areas; however, these areas were somewhat under-represented in this survey. The absence of QPX in areas having more moderate salinities ( 15 to $25 \mathrm{ppt}$ ) may be related to a limitation in the parasite's salinity tolerance or may reflect sampling bias. Published reports on the occurrence of QPX in Canada and Massachusetts do not include reference to the salinities of the areas where QPX was found, but most sites were located in coastal bays so salinities were likely greater than 25 ppt. Salinity is an important factor controlling the distribution and pathogenicity of other molluscan parasites (Haskin et al. 1982, Ford \& Haskin 1988, Burreson \& Ragone Calvo 1996), so it is not unreasonable to suspect that it may have a limiting effect on QPX. Further investigation will be required to clarify the role of salinity in regulating the distribution and activity of QPX.

Of the 3 sites where QPX was found, only one, Black Narrows, was monitored seasonally. Samples were collected in July, August, October, November, February, May, and June. QPX was present in all samples; however, differences in prevalence and intensity were observed. These differences may reflect sampling variability or may be indicative of parasite seasonality. The highest prevalences and most severe infections were observed in November and May. The high prevalence in May coincided with clam mortalities, which may have been associated with QPX. QPX appeared to be most active during November and May as division stages of the parasite were commonly observed at this time. Sporangia were only observed in the October, November, and May samples. The highest frequencies of moribund QPX occurred in August, October and February. In Massachusetts, hard clam mortalities caused by QPX were highest in late summer and early fall (Smolowitz et al. 1998). Temperature has been demonstrated to have a profound influence on other molluscan host-parasite systems (Chu \& Greene 1989, Burreson \& Ragone Calvo 1996) and it is likely that QPX activity and pathogenicity are also correlated with temperature.

A comparison of QPX in Canadian clams (CA QPX) and QPX in Massachusetts clams (MA QPX) has been presented by Smolowitz et al. (1998). Many morphological similarities were noted suggesting that the organisms were the same. Differences were also noted, particularly in respect to site of QPX lesions, host defense response, presentation of extracellular net material and staining affinities. MA QPX was most commonly observed in mantle and gill tissues while CA QPX was primarily observed in muscle and connective tissues. Inflammation and partial encapsulation were the only host response noted in Canadian clams (Whyte et al. 1994). In contrast the QPX infected clams from Massachusetts exhibited inflammation and specific cellular immune responses including encapsulation, phagocytosis, and the formation of multinucleated giant cells (Smolowitz et al. 1998). In respect to lucent or cell-free regions, the occurrence of a mucofilamentous net was regularly observed surrounding MA QPX while lucent areas encircling CA QPX rarely contained filamentous or net-like material. Whyte et al. (1994) believed that the lucent areas were indicative of host tissue lysis but Smolowitz et al. (1998) suggest that the cell-free regions noted by Whyte et al. (1994) may also have contained a mucoid material, which was removed during histological processing. Finally, differences in the affinities for special stains were also 

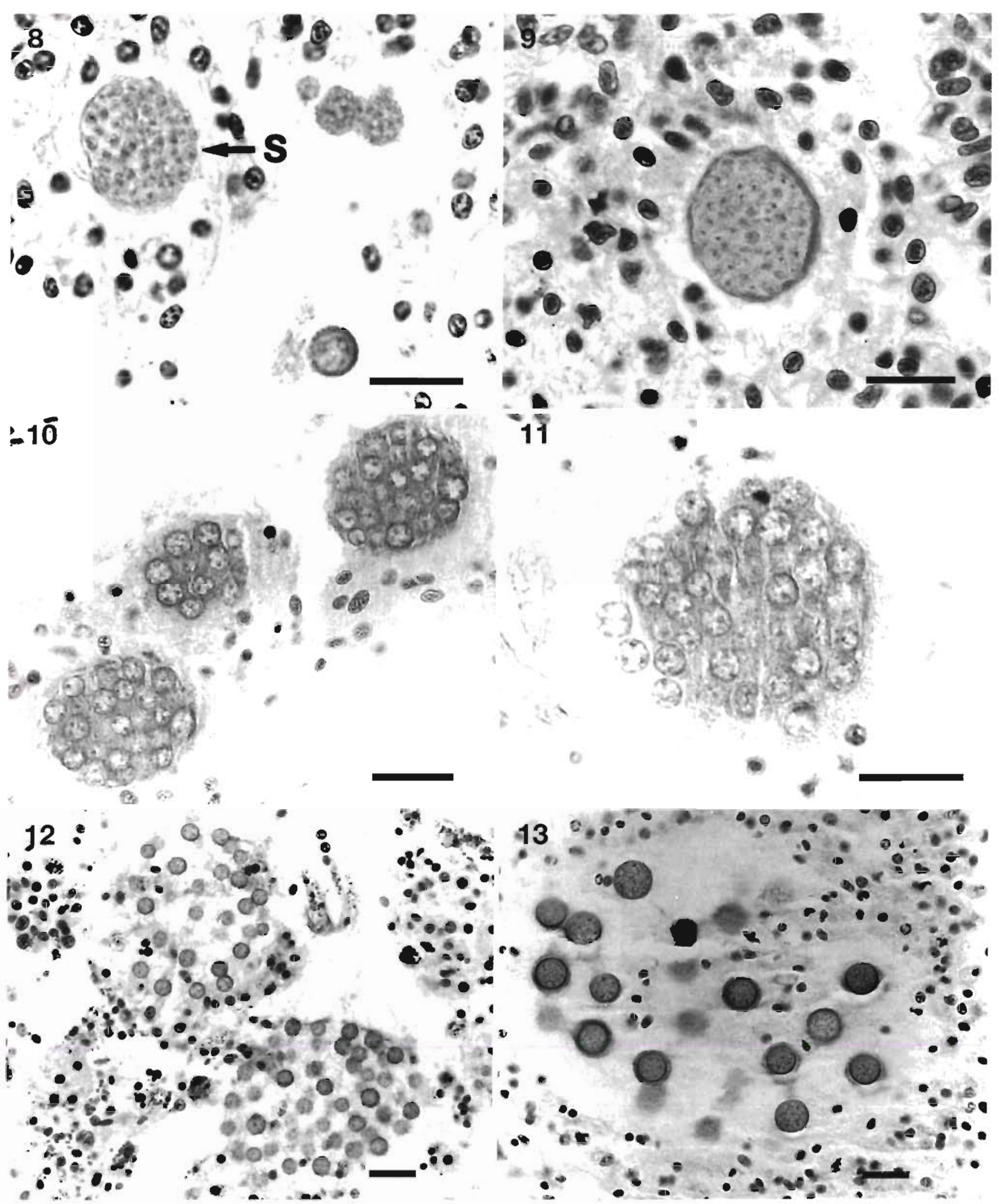

Figs. 8 to 13. Various morphological forms of QPX observed in Mercenaria mercenaria host tissues. Figs. 8 \& 9. QPX sporangia (S) $(\mathrm{H} \& \mathrm{E}$, scale bars $=20 \mu \mathrm{m})$. Fig. 10. Developing endospores within QPX sporangia $(\mathrm{H} \& \mathrm{E}$, scale bar $=20 \mu \mathrm{m})$. Fig. 11. Endospores upon release from sporangia $(\mathrm{H \& E}$, scale bar $=20 \mu \mathrm{m})$. Figs. $12 \& 13$. Dissociating clusters of immature thalli (H\&E, scale bars $=$ 

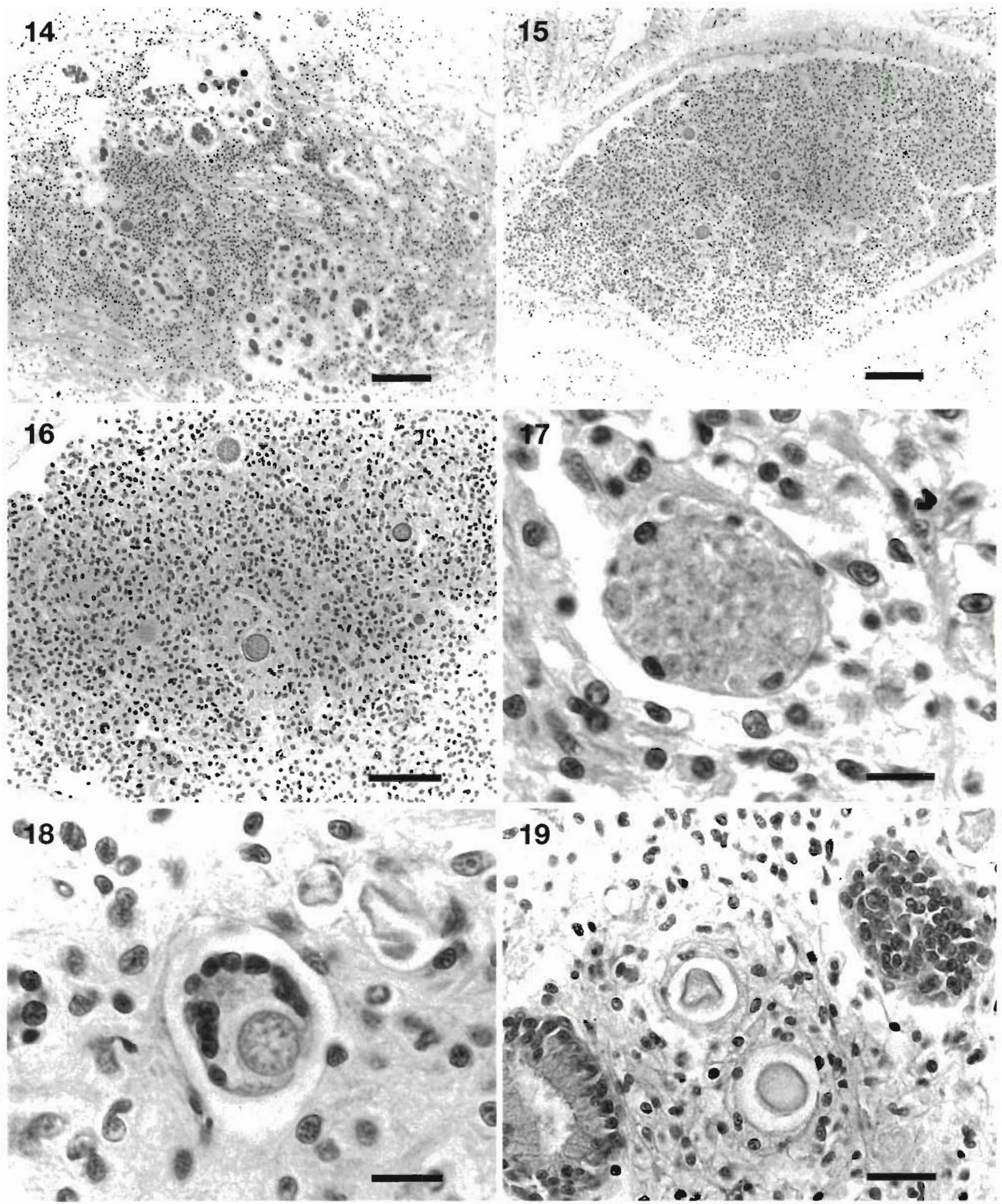

Figs. 14 to 19. Mercenaria mercenaria. Host response to QPX cells. Fig. 14. Multiple foci of QPX demonstrating cell-free regions and QPX-elicited hemocytic infiltration (H\&E, scale bar $=100 \mu \mathrm{m})$. Figs. $15 \& 16$. QPX lesion within kidney tubule showing intensive infiltration of hemocytes (H\&E, scale bars $=100 \mu \mathrm{m}$ and $50 \mu \mathrm{m}$ for Figs. I5 \& 16, respectively). Fig. 17. Hemocytes encapsulating QPX sporangia $(\mathrm{H} \& \mathrm{E}$, scale bar $=20 \mu \mathrm{m})$. Fig. 18. QPX phagocytozed by multinucleated giant cell $\left(\mathrm{H} \& \mathrm{E}_{\text {, }} \mathrm{scale}\right.$ bar $\left.=10 \mu \mathrm{m}\right)$. Fig. 19. Moribund QPX cells encapsulated by host hemocytes, QPX cell walls appear intact while cytoplasm and nuclear material appears degraded (H\&E, scale bar $=20 \mu \mathrm{m})$ 
noted. PAS and GMS stained only the cell wall of CA QPX while with MA QPX the cell wall and cytoplasm stained with PAS and only the nucleus stained with GMS. Differences in staining may suggest that the organisms are slightly different (Smolowitz et al. 1998). Alternatively, differences in fixation (Whyte et al. used Davidson's AFA while Smolowitz et al. used Formalin) and staining technique could influence stain differentiation.

The QPX organism found in Virginia (VA QPX) is more similar to MA QPX than to CA QPX in that the size of the parasite was very similar; the parasite elicited host responses including phagocytosis, encapsulation, and the formation of multinucleate giant cells; infections were also most commonly observed in mantle and gill tissues, and mucofilamentous net material was often observed in the cell-free region surrounding the parasite. Differentiation of the mucofilamentous net material of VA QPX with AB/PAS stain supports the observation of Smolowitz et al. (1998) that this material is comprised of a mucopolysaccharide.

VA QPX did differ from MA QPX in several important aspects. First, gross pathological signs such as nodules and chipped valves were not observed in VA QPX infected clams. Second, lesions, mucoid net production and lucent regions of VA QPX were generally much less extensive than that of MA QPX. Third, moribund parasite cells were more frequently observed in Virginia than in Massachusetts. Finally, and most importantly, VA QPX prevalences were lower and the parasite was not associated with significant clam mortalities. Abnormal clam mortalities and a concomitant high QPX prevalence were reported in May 1997 at the Chincoteague Bay site, but this was the only documentation of what may have been QPX associated mortality. These comparisons suggest that the QPX organism in Massachusetts may be more pathogenic than the QPX organism in Virginia.

Differences in the pathogenicity of VA QPX and MA $\mathrm{QPX}$, as suggested by the above comparison, could be related to several factors. Such factors include environmental conditions, parasite virulence and host physiology. One possibility is that differences in QPX pathogenicity are associated with differences in the proliferation of the mucoid net material (Smolowitz pers. comm.). An extensive mucofilamentous net may impair the effectiveness of the clams cellular defense response. Smolowitz et al. (1998) suggest that the mucofilamentous net of QPX acts as a physical barrier that prevents hemocyte migration and subsequent phagocytosis of the parasite. Reduced net formation by VA QPX may enable the clams to more effectively eliminate QPX infections. Pehaps host factors such as defense capacity or physiological condition may make the Virgnia clams less susceptible to the disease.
Should differences in the pathogenicity be related to genetically based host factors, a potential management strategy for mitigation of QPX in Massachusetts emerges, as VA broodstocks may yield clam seed that exhibits reduced susceptibility to QPX.

Presently, the distribution of QPX in Virginia appears to be restricted to only a few areas and prevalences of the parasite have been low. However, with a high concentration of hard clam aquaculture occurring near the affected areas and in adjacent embayments, we remain concerned that the disease may spread and threaten hard clam aquaculture in the region. Since little is known about the basic biology of QPX, it is impossible at present to determine what the impact of the parasite will be in Virginia or to advise industry on avoidance/controi strategies. Basic parameters such as temperature and salinity tolerance, seasonality, and whether the parasite can be transmitted directly from clam to clam are unknown. Further investigations are needed to elucidate key aspects of the epizootiology and pathobiology of QPX. Subsequently we will be able to determine and mitigate the potential threat of QPX to the hard clam fishery and aquaculture industry.

Acknowledgements. The authors thank Dr Roxanna Smolowitz for sharing her expertise and histological sections for the comparison of MA and VA QPX with histology; Mike Oesterling, Dr Mark Luckenbach, Jake Taylor and other VIMS Eastern Shore Laboratory staff members, for assisting with the coordination of sample collection; and the numerous hard clam harvesters and culturists who generously contributed samples. VIMS contribution 2118.

\section{LITERATURE CITED}

Anonymous (1996) Virginia aquaculture 1995 survey report Virginia Agriculture Statistics Service. Richmond

Bower SM (1987) Labyrinthuloides haliotidis n. sp. (Protozoa: Labyrinthomorpha), a pathogenic parasite of small juvenile abalone in a British Columbia mariculture facility. Can J Zool 65:1996-2007

Burreson EM, Ragone Calvo LM (1996) Epizootiology of Perkinsus marinus disease of oysters in Chesapeake Bay, with emphasis on data since 1985. J Shellfish Res 15(1):17-34

Chu FLE, Greene KH (1989) Effect of temperature and salinity on in vitro culture of the oyster pathogen, Perkinsus marinus (Apicomplexa: Perkinsea). J Invertebr Pathol 53: $260-268$

Drinnan RE, Henderson EB (1963) 1962 mortalities and a possible disease organism in Nequac quahogs. Annual Report B11. Biological Station, St. Andrews, New Brunswick

Ford SE, Haskin HH (1988) Comparison of in vitro salinity tolerance of the oyster parasite, Haplosporidium nelsoni (MSX) and hemocytes from the host, Crassostrea virginica. Comp Biochem Physiol 90A(1):183-187

Hanion RT, Forsythe JW (1990) Diseases caused by microorganisms. In: Kinne $O$ (ed) Diseases of marine animals, Vol III, Chap 1. Biologische Anstalt Helgoland, Hamburg, p $40-43$ 
Haskin HH, Ford S, O Conner D (1982) Environmental influences on MSX infection patterns in Delaware Bay. J Shellfish Res 2(1):97

Howard DW, Smith CS (1983) Histological techniques for marine bivalve mollusks. Technical Memorandum NMFSF/NEC-25. National Marine Fisheries Service, Woods Hole

Kraeuter JN, Castagna M (1989) Factors affecting the growth and survival of clam seed planted in the natural environment. In: Manzi JJ, Castagna M (eds) Clam mariculture in North America. Elsevier, New York, p 149-165

McLean N, Porter D (1982) The yellow-spot disease of Tritonia diomeda Bergh, 1894 (Mollusca: Gastropoda: Nudibranchia): encapsulation of the Thraustochytriaceous

Editorial responsibility: Albert Sparks,

Seattle, Washington, USA parasite by host amoebocytes. J Parasitol 68:243-252

Porter D (1989) Phylum Labyrinthulomycota. In: Margulis L, Corliss JO, Melkonian M, Chapman DJ (eds) Handbook of Protoctista. Jones and Bartlett Publishers, Boston p 388-397

Smolowitz R, Leavitt D, Perkins F (1998) Observations of a protistan disease similar to QPX in Mercenaria mercenaria (hard clams) from the coast of Massachusetts. J Invertebr Pathol 71:9-25

Whyte SK, Cawthorn RJ, McGladdery SE (1994) QPX (Quahaug Parasite X), a pathogen of northern quahaug Mercenaria mercenaria from the Gulf of St. Lawrence, Canada Dis Aquat Org 19:129-136

Submitted: January 18, 1998; Accepted: March 31, 1998 Proofs received from author(s): July 20, 1998 